NBER WORKING PAPER SERIES

THE EFFECT OF INCREASED TAX

RATES ON TAXABLE INCOME AND

ECONOMIC EFFICIENCY: A

PRELIMINARY ANALYSIS OF THE

1993 TAX RATE INCREASES

Martin Feldstein

Daniel Feenberg

Working Paper 5370

NATIONAL BUREAU OF ECONOMIC RESEARCH

1050 Massachusetts Avenue

Cambridge, MA 02138

November 1995

Martin Feldstein is professor of economics at Harvard University and president of the National Bureau of Economic Research. Daniel Feenberg is a Research Associate of the NBER. We are grateful to Larry Lindsey and Larry Summers for discussions about this research and to participants in the 1995 NBER Tax Policy and the Economy conference for comments on an earlier draft. This paper is part of NBER's research programs on the economic effects of taxation, and Public Economics. Any opinions expressed are those of the authors and not those of the National Bureau of Economic Research.

(C) 1995 by Martin Feldstein and Daniel Feenberg. All rights reserved. Short sections of text, not to exceed two paragraphs, may be quoted without explicit permission provided that full credit, including () notice, is given to the source. 


\title{
THE EFFECT OF INCREASED TAX \\ RATES ON TAXABLE INCOME AND \\ ECONOMIC EFFICIENCY: A \\ PRELIMINARY ANALYSIS OF THE \\ 1993 TAX RATE INCREASES
}

\begin{abstract}
The 1993 tax legislation raised marginal tax rates to 36 percent from 31 percent on taxable incomes between $\$ 140,000$ and $\$ 250,000$ and to 39.6 percent on incomes above $\$ 250,000$. This paper uses recently published IRS data on taxable incomes by adjusted gross income class to analyze how the 1993 tax rate increases affected taxable income, tax revenue, and economic efficiency. Our estimates are based on a difference-in-difference procedure comparing growth of taxable incomes among taxpayers with AGIs over $\$ 200,000$ to the growth of incomes of lower income taxpayers. We use the NBER TAXSIM model to adjust for interyear differences in the composition of the two taxpayer groups.

The results show that high income taxpayers would have reported 7.8 percent more taxable income in 1993 than they did if their tax rates had not increased. Because of the high threshold for the increase in tax rates, this decline in taxable income caused the Treasury to lose more than half of the extra revenue that would have been collected if taxpayers had not changed their behavior.

The deadweight loss caused by the higher marginal tax rates (including the effects on labor supply and on consumption of goods and services favored by deductions and exclusions) is approximately twice as large as the $\$ 8$ billion in revenue raised by the 1993 tax rate.

Several possible statistical biases could cause the estimated effect of the tax changes to either underestimate or overestimate the true long-run effect. The paper concludes with a discussion of these problems and of plans for future analysis.

Martin Feldstein

National Bureau of Economic Research 1050 Massachusetts Avenue

Cambridge, MA 02138

Daniel Feenberg

National Bureau of Economic Research 1050 Massachusetts Avenue

Cambridge, MA 02138
\end{abstract}




\title{
The Effect of Increased Tax Rates on Taxable Income and Economic Efficiency: A Preliminary Analysis of the 1993 Tax Rate Increases
}

\author{
Martin Feldstein and Daniel Feenberg*
}

Although several studies have shown that lowering income tax rates in the 1980s raised taxable incomn and labor supply, there are no studies of the effects of increases in marginal tax rates. The present paper fills that gap by analyzing taxpayer behavior after the 1993 increase in personal tax rates using data from 1993 tax returns recently released by the Treasury. ${ }^{2}$

The sensitivity of taxable income to changes in marginal tax rates is obviously important because it determines the effect of tax rate changes on revenue. Less obvious, the deadweight loss that results from a change in marginal tax rates is proportional to the compensated elasticity of

'Eissa (1995), Lindsey (1987) and Navratil (1995) studied the effect of the 1981 tax rate reductions on taxable income and on the labor supply of married women. Auten and Carroll (1994a), Eissa (1994), Feenberg and Poterba (1993), Feldstein (1995a and 1995b) and Navratil (1995) studied the effects of the 1986 tax rate reductions. The actual panel data used by Feldstein (1995a) and Auten and Carroll (1994a) shows that, despite the inherent problems with the synthetic panels used in other studies, the results of those studies are very much in line with the more accurate panel data. See also Auerbach (1994 and 1995) for evidence on the tendency of official revenue forecasts to overstate actual revenue because of taxpayer responses.

${ }^{2}$ The earlier draft of this paper that was distributed to conference participants was based on the preliminary IRS tax statistics for 1993 (Cruciano, 1995) while the current version uses the final IRS statistics for 1993.

* Martin Feldstein is professor of economics at Harvard University and president of the National Bureau of Economic Research. Daniel Feenberg is a Research Associate of the NBER. We are grateful to Larry Lindsey and Larry Summers for discussions about this research and to participants in the 1995 NBER Tax Policy and the Economy conference for comments on an earlier draft. This study is part of the NBER's research program on the economic effects of taxation. 
taxable income with respect to the net of tax rate. ${ }^{3}$ For both reasons, it is important to estimate the effect of tax rate changes on taxable income.

In this paper, we report the results of a preliminary analysis of the effects of the 1993 tax rate increases. The analysis is consistent with the basic finding of the previous studies of the tax rate decreases of the $1980 \mathrm{~s}$ that taxable income is quite sensitive to marginal tax rates. Our estimates imply that the rise in marginal tax rates in 1993 led to a substantial decline in taxable income. As a result of this sensitivity, the 1993 tax rate increases raised less than one-half of the revenue that would have been raised with no behavioral response. ${ }^{45}$

Moreover, the compensated ela iicity of taxable income with respect to the net of tax rate (i.e., one minus the marginal tax rate) that we estimate on the basis of the 1993 behavior implies that

${ }^{3}$ See Feldstein (1995c) for a demonstration that the overall deadweight loss of the income tax that results from distortions in labor supply, in tax deductible expenditures, and in the form of compensation is proportional to the elasticity of taxable income with respect to the net of tax rate, i.e., one minus the marginal tax rate.

${ }^{4}$ Feldstein and Feenberg (1993) analyzed the proposed 1993 tax rate increases and estimated that taxpayer responses might cut the projected revenue by about 50 percent if taxpayers responded to the higher marginal tax rates by reducing their taxable incomes by 5 percent. That analysis used TAXSIM data on individual tax returns (for 1989 adjusted to 1993 levels) but did not have actual taxpayer experience on which to base the estimated response of taxable income. Feldstein (1995a) showed that an elasticity of one of taxable income with respect to the net of tax rate would eliminate virtually all of the projected tax revenue.

${ }^{5}$ In the language of Washington tax policy analysis, the actual revenue effect of the tax rate increases was less than one-half of the "static" forecast. The Treasury Department's revenuc estimate was not strictly a static forecast but assumed that behavioral changes would reduce 1993 personal income tax revenue by 7 percent as taxpayers responded to the higher marginal tax rates by changes in realized capital gains, in the use of tax exempt bonds, in shifts from subchapter $\mathrm{S}$ to subchapter $\mathrm{C}$ corporations, and in various forms of noncompliance and tax sheltering (Auten and Carroll, 1994). The method used by the Treasury and the Joint Committee on Taxation of the Congress explicitly ignores changes in labor supply, in the form of compensation, and in a variety of deductions (Auten and Carroll,1994; Feldstein, 1994). 
the deadweight loss associated with the 1993 tax rate increases is nearly twice as large as the net revenue raised by those rate increases. This means that for every dollar of additional revenue collected by the government as a result of the higher tax rates, taxpayers experience a decline in their well-being equivalent to three dollars as a result of the induced changes in work, in the form of compensation. and in tax deductible expenditures.

Section 1 of the paper reviews the nature of the 1993 tax increases and the ways in which the resulting income and substitution effects could affect representative taxpayers. Section 2 discusses the data and method used in the current analysis. Section 3 describes our estimated taxpayer responses and the implied net revenue effects of the 1993 tax rate increases. In the fourth section we present the implied elasticities. Section 5 reports the associated deadweight losses of the tax rate increases. The sixth section applies the estimated elasticities to calculate the effect of eliminating the ceiling on the health insurance payroll tax base that began in January 1994. Section 7 discusses possible biases in our estimate of taxpayer responses, including the relation between the observed short-term effects and the likely longer-term effects. The final section summarizes conclusions and caveats and points to the direction for future research.

\section{The 1993 Tax Rate Increases}

The tax legislation enacted in 1993 raised the marginal tax rate from 31 percent to 36 percent on taxable incomes between $\$ 140,000$ and $\$ 250,000$ (between $\$ 115,00$ and $\$ 250,000$ for single taxpayers) and to 39.6 percent on taxable income in excess of $\$ 250,000 .^{6}$ In addition, the legislation

${ }^{6}$ Because of the loss of 3 percent of itemized deductions at high income levels the effective marginal tax rates are about one percent higher than the statutory 31 percent, 36 
eliminated the $\$ 135,000$ ceiling on the Medicare component of the payroll tax, effectively adding an additional 2.9 percent combined employer-employee tax on the compensation component of taxable income. Because this HI payroll tax did not come into effect until January 1994, we ignore it in our calculations. To the extent that high income taxpayers recognized that their marginal tax rates would rise in 1994 and responded by shifting compensation to 1993, the observed reduction in taxable income in 1993 is smaller than it would otherwise be and we underestimate the longer-run loss of tax revenue and the implied sensitivity of taxes to the net of tax rate. We can however use our estimates of the sensitivity of taxable income to tax rates to estimate the effect of the higher HI tax base. We return to do this in section $6 .^{7}$

Because the marginal tax rate applies only to incomes over a very high threshold, for most of the high income taxpayers there is a substantial increase in the marginal tax rate but little increase in the average tax rate on their initial ("no behavioral response") income. The structure of the tax rate increase therefore has the likely effect of reducing taxable income for many taxpayers to such an extent that the revenue $\cdots$ th the higher margin..! tax rates is very much smaller than the traditional "static" (no behavioral response) estimates would imnly. ${ }^{8}$

percent and 39.6 percent rates that we use in our calculations. We ignore this in our calculations.

${ }^{7}$ The 1993 legislation also increased the tax rate for the Alternative Minimum Tax and changed the AMT rules to broaden its base. Since the AMT only collects an incremental $\$ 1.1$ billion or 0.8 percent of tax revenue among the high income taxpayers whom we study, we ignore it in our analysis. To the extent that some taxpayers became subject to the AMT as a result of the 1993 legislation, they would have experienced a decline in their marginal tax rate and may have responded by increasing their taxable income. Since we do not take the AMT into account explicitly in our analysis, such behavior would cause us to underestimate the effect of higher marginal tax rates on taxpayer behavior.

${ }^{8}$ We emphasized this in Feldstein and Feenberg (1993) and in Feldstein (1995a). 
An analysis of two representative high income taxpayers shows how this would occur in practice. Consider first a couple with $\$ 180,000$ of taxable income, the level of income that the Clinton administration identified as the median income among those taxpayers whose tax rates were increased in the 1993 legislation. With no behavioral response, the increase in the marginal tax rate from 0.31 to 0.36 on taxable income between $\$ 140,000$ and $\$ 180,000$ would raise additional revenue of $\$ 2000$. However, the tax rate increase reduces the net of tax share that the taxpayer receives from 0.69 to 0.64 , a decrease of 7.2 percent. If this decrease in the net of tax share causes taxable income to decline by five percent, ${ }^{9}$ taxable income falis from $\$ 180,000$ to $\$ 171,000$. This reduces the personal income tax revenue by 31 percent of the $\$ 9,000$ decline in taxable income, a revenue decrease of $\$ 2790$. The combination of this revenue loss and of the additional $\$ 1550$ collected by levying a 5 percent tax on the $\$ 31,000$ of taxable income (the difference between $\$ 171,000$ of taxable income and the threshold of $\$ 140,000$ for the iigher tax rate) causes the income tax liability of this couple to decline by $\$ 1240$ as a result of the tax change.

There may also be a loss of OASDHI payroll tax revenue. For example, if the $\$ 180,000$ of taxable income reflected the husband's wage income of $\$ 130,000$ and the wife's wage of $\$ 50,000$ (plus investment income equal to itemized deductions and other adjustments), the decline in taxable income could reduce the $\mathrm{HI}$ tax revenue at a 2.9 percent rate if part of the decline is due to a reduction in the husband's taxable compensation and could reduce the OASDHI revenue at a 15.3 percent rate if part of the decline in taxable income is due to a reduction in the wife's compensation.

${ }^{9} \mathrm{~A}$ five percent decline of taxable income in response to the 7.2 percent decline in the net of tax share is roughly in line with the evidence presented in this paper and less than the decline implied by the evidence presented by Auten and Carroll (1994a), Feldstein (1995a) and Lindsey (1987). 
Our analysis assumes that the compensation of the husband and the compensation of the wife both decline in the same proportion as overall taxable income. ${ }^{10}$ Reducing the husband's wage income by 5 percent of $\$ 130,000$ implies a loss of $\mathrm{HI}$ tax revenue of $\$ 188$. Reducing the wife's wage income by 5 percent of $\$ 50,000$ implies a loss of OASDHI tax revenue of $\$ 382$. The total revenue loss caused by the higher personal tax rate is thus the sum of the lost personal tax revenue $(\$ 1240)$ and the loss of the payroll tax revenue $(\$ 570)$ for a total revenue loss of $\$ 1810$.

The revenue effect of the increase in 1993 tax rates becomes positive at higher levels of taxable income. Consider the effect on a couple with taxable income of $\$ 500,000$, including $\$ 300,000$ of taxable compensation of the husband and $\$ 50,000$ of taxable compensation of the wife. Their marginal tax rate rises from 0.31 to 0.396 , reducing the net of tax share from 0.69 to 0.604 , a decline of 12.7 percent. Assume that this induces a decline in taxable income of eight percent, from $\$ 500,000$ to $\$ 460,000 .^{\prime \prime}$ The net effect on personal income tax revenue is therefore an additional 5 percent tax on the income between $\$ 140,000$ and $\$ 250,000$ (a tax increase of $\$ 5,500$ ), an additional 8.6 percent on the income between $\$ 250,000$ and $\$ 460,000$ (a tax increase of $\$ 18,060$ ), and a loss of revenue at the initial 31 percent on the reduced $\$ 40,000$ (a tax decrease of $\$ 12,400$ ); the net effect is therefore a net personal income tax rise of $\$ 11,160$. The offsetting loss of payroll tax revenue is small since the decline in the husband's wage and salary income is all in the untaxed range above $\$ 135,000$. The 8 percent decline in the wife's wage income from $\$ 50,000$ causes a $\$ 612$

\footnotetext{
${ }^{10}$ See Feldstein and Feenberg (1995) for our method of distributing total wage and salary income between husbands and wives. We also include add 50 percent of business and professional income (schedule $\mathrm{C}$ income) to the husband's taxable compensation.

${ }^{11}$ See footnote 9 about the plausibility of this magnitude of response.
} 
loss of payroll tax revenue, bringing the government's overall net revenue gain to $\$ 10,518$. For comparison, the static revenue estimate based on the assumption that taxable income would remain at $\$ 500,000$ would be $\$ 27,000$. The actual revenue gain for this couple is thus only slightly more than one third of the static estimate.

We had planned to study the actual effects of the 1993 tax changes as soon as the Treasury Department's panel data for 1993 became available, using the method applied to the 1986 data in Feldstein (1995a). We were struck, however, by an article in the New York Times that appeared on April 17, 1995 with the headline "Well-to-Do Paid 16\% More in Taxes in '93, Study Says."

The story reported that "The taxes of well-to-do Americans surged 16 percent in 1993, the first year of revisions pressed into law by President Clinton. People who earned $\$ 100,000$ or more owed the Government $\$ 31$ billion more, compared with their tax bills in 1992 according to computer assisted analysis of Internal Revenue Service data by the Associated Press. Everyone else owed about $\$ 3$ billion more."

It was not clear to us why the analysis included the more than 3 million taxpayers with incomes between $\$ 100,000$ and $\$ 200,000$ of adjusted gross incomes since few of them would have been affected by the increase in marginal tax rates on taxable incomes over $\$ 140,000$. In contrast, the average taxable income among taxpayers with AGIs of $\$ 200,000$ is slightly more than $\$ 140,000$. Among the fewer than one million taxpayers with adjusted gross incomes over $\$ 200,000$, 98 percent were affected by the increase in tax rates while only 9.5 percent of taxpayers with AGI between $\$ 100,000$ and $\$ 200,000$ were affected. We suspected, moreover, that the general rise in the taxes paid by households with incomes over $\$ 100,000$ reflected the rise in nominal incomes and the shift of taxpayers who were not affected by the 1993 tax rate increases into higher tax brackets. 
The study reported in the New York Times was widely noted as evidence that the 1993 tax rates had raised substantial revenue at the top and that the direct revenue effect of higher marginal tax rates had not been offset by reductions in taxable income. Since the individual taxpayer panel data would not be available for several years, we decided to investigate the available aggregate evidence in more detail.

\section{The Data and Method of Analysis}

Our analysis uses the Treasury Department's recently published tabulations based on the individual income tax returns for 1993. These tabulations provide information on taxable income and other tax return items classified by adjusted gross income (AGI) class. We focus our analysis on taxpayers with AGI greater than $\$ 200,000$ and ask how this group, which we refer to at the "high income taxpayers," responded to the 1993 tax changes.

Since we do not have data for the same individual taxpayers in 1992 and 1993, we cannot examine how the actual taxable incomes of the 1992 high income taxpayers changed between those two years. We can, however, estimate how adjusted taxable income changed for the highest income taxpayers as a group between 1992 and $1993 .{ }^{12}$ We compare the observed change in the taxable incomes of these high income taxpayers with our estimate of what that change would have been if they had not modified their taxable income in response to the rise in tax rates.

We base this estimate of their no-behavioral-response 1993 taxable incomes on the behavior

\footnotetext{
${ }^{12}$ This is essentially the method used by Lindsey (1987).
} 
of taxpayers with adjusted gross incomes between $\$ 50,000$ and $\$ 200,000 .{ }^{13}$ In effect, we assume that the relative distribution of income would have remained the same (with all taxpayers subject to a common percentage rise) and attribute the difference from this benchmark to the tax change. ${ }^{14}$

Because the tax rate increases did not apply to capital gains (recall that the tax on capital gains remained at a maximum of 28 percent) we look at taxable income excluding capital gains taxed at 28 percent. We also adjust the measure of taxable income by adding back in the personal exemptions and standard deductions because their values changed between 1992 and $1993 .{ }^{15}$ We call the resulting figure "adjusted taxable income" (ATI).

Our estimate of what adjusted taxable incomes would have been in 1993 among high income taxpayers if there had been no change in behavior is derived with the help of the NBER TAXSIM model, using individual tax returns for 1991, the most recent year for which such data are available. These data are a stratified random sample of more than 100,000 tax returns selected by the Internal

${ }^{13}$ About 93 percent of high income taxpayers were subject to marginal tax rates of 36 percent or 39.6 percent; in contrast, only 2 percent of taxpayers with adjusted gross incomes of $\$ 50,000$ to $\$ 200,000$ were taxed at these high rates. These figures are based on our analysis of he Treasury Department's 1991 Public Use Sample of tax returns adjusted to 1993 levels.

${ }^{14}$ If anything, the tendency for higher incomes to grow more rapidly than lower incomes (see, e.g., the trend in the data presented in Feenberg and Poterba, 1993) suggests that our method underestimates the no-behavioral-response level of 1993 incomes of high income taxpayers and therefore underestimates the depressing effect of high marginal tax rates.

Other factors may have influenced the groups' incomes in different ways. This could cause our estimate to overstate or understate the true elasticity. We return to these possible sources of bias in section 7 below.

${ }^{15}$ The personal exemptions and standard deduction are extremely small as a proportion of income for the high income group. The standard deduction was only $\$ 300$ million for this group in 1993, less than one tenth of one percent of taxable income. Personal exemptions were about one billion or less than one half of one percent of taxable income. 
Revenue Service to overweight high income returns. We begin by "aging" these data to 1992 in a way that causes the adjusted taxable income among 1992 high income taxpayers to match the published amount. ${ }^{16}$ This sample of synthetic 1992 individual tax returns is then used to derive a baseline sample of 1993 high income tax returns corresponding to the 1992 tax rules (or. equivalently, to the assumption that adoption of the 1993 tax rules did not change taxpayer behavior).

The key to deriving this synthetic sample of no-behavioral-response 1993 high income tax returns is to assume that the taxable incomes of the high income taxpayers would increase at the same rate as the taxable incomes of those with AGIs between $\$ 50,000$ and $\$ 200,000$ since their tax rates did not change in $1993 .{ }^{17}$ The published statistics for 1993 indicate that the adjusted taxable incomes of taxpayers with 1993 AGIs of $\$ 50,000$ to $\$ 200,000$ was 8.2 percent greater than the adjusted taxable incomes of taxpayers with 1992 AGIs of $\$ 50,000$ to $\$ 200,000$. This of course does

${ }^{16}$ In the earlier draft of this paper that was prepared for the Tax Policy and the Economy conference we used the "preliminary" totals for 1993. In the current paper, we are able to use the published "final" totals.

${ }^{17}$ To the extent that some of those in the $\$ 50,000$ to $\$ 200,000$ AGI class did experience tax rate increases which reduced their 1993 taxable incomes below what they would otherwise have been, our method of comparing the changes in taxable incomes in the two groups underestimates the effect of the tax rate rise on taxable income. But as noted above, on the basis of the 1991 data, we estimate that only two percent of taxpayers in the $\$ 50,000$ to $\$ 200,000 \mathrm{AGI}$ class in 1993 would have been subject to higher marginal tax rates.

We also developed an estimate of the baseline no-behavioral-response taxable incomes of the 1993 high income taxpayers by assuming that their taxable incomes would rise at the same rate as all taxpayers with AGIs below $\$ 200,000$. Although this procedure is inferior in principle to using the taxpayer with AGIs between $\$ 50,000$ and $\$ 200,000$ because the lower income groups are potentially subject to quite different market forces and income composition than the group of taxpayers with incomes between $\$ 50,000$ and $\$ 200,000$, the results for this "full sample group" are very similar to the results for the $\$ 50,000$ to $\$ 200,000$ group. 
not imply that on average each individual's taxable income rose by 8.2 percent since the general rise in incomes shifted more taxpayers into the $\$ 50,000$ to $\$ 200,000$ AGI class. The TAXSIM data on individual tax returns imply that this 8.2 percent increase in the total income of the $\$ 50,000$ to $\$ 200,000$ AGI class occurs if all individual taxable incomes grow by 3.4 percent between 1992 and 1993. ${ }^{18}$ This substantial difference shows the danger of trying to base comparisons across years or across income groups on published data by AGI class without using microeconomic data to adjust for the changing composition of the groups.

Having derived this key 3.4 percent individual income growth parameter, we raise the 1992 adjusted taxable income of every taxpayer by this amount. With this growth of ATI at the individual level, the aggregate ATI among taxpayers with 1993 AGIs over $\$ 200,000$ would have been $\$ 399$ billion, a increase of 7.0 percent from the $\$ 374$ billion in the same AGI class in 1992 .

In contrast, the published estimate of adjusted taxable income among taxpayers with adjusted gross incomes over $\$ 200,000$ in 1993 actually declined from $\$ 374$ billion in 1992 to $\$ 364$ billion in $1993 .{ }^{19},{ }^{20}$ If the study referred to in the New York Times story had divided taxpayers at $\$ 200,000$ of adjusted gross incomes (in order to focus on those : :ho were likely to have experienced high

${ }^{18} \mathrm{We}$ also rescale the sampling weights to reflect a 1.1 percent increase in the adult population between 1992 and 1993 .

${ }^{19}$ Such a reduction is very unusual. In the preceding decade, taxable income excluding capital gains among taxpayers with AGI over $\$ 200,000$ declined only in 1988 and 1991 . The 1991 decline may reflect the increase in the top tax rate that year.

${ }^{20}$ The 1993 adjusted taxable income among taxpayers with AGIs over $\$ 200,000$ is derived from the total taxable income of $\$ 427$ billion in this group by subtracting $\$ 64$ billion of capital gains and adding back in $\$ 0.3$ billion of standard deductions and $\$ 1.5$ billion of personal exemptions. 
rates), the analysis would have concluded that those with incomes over $\$ 200,000$ experienced an aggregate decrease of taxable incomes of $\$ 3$ billion while the taxable incomes of those in lower AGI groups saw their incomes rise by $\$ 60$ billion. $^{21}$

Part of the observed decline was due to the fact that some taxpayers who had taxable incomes over $\$ 200,000$ in 1992 dropped into the next lower AGI class in 1993 as part of their reaction to the higher marginal tax rates. It would of course be inappropriate to compare the no-behavioral-response incomes of those who are projected to have 1993 income over $\$ 200,000$ to the actual incomes of those with more than $\$ 200,000$ of AGI without taking into account the taxpayers who migrated to the lower AGI class.

To adjust for this shift in taxpayers, we note that, with the no behavioral response assumption, the number of taxpayers with AGI greater than $\$ 200,000$ is projected to increase by 80,000 between 1992 and 1993. In contrast, the observed number of taxpayers with adjusted gross incomes over $\$ 200,000$ actually increased by only 38,000 . We infer that 42,000 taxpayers dropped from the AGI greater than $\$ 200,000$ class to the lower class. We therefore augment the estimated adjusted taxable income in the AGI greater than $\$ 200,000$ class by an estimate of the taxable income of these 42,000 returns. To be conservative, we attribute to these 42,000 taxpayers an average "actual" adjusted taxable income equal to the projected average ATI among 1993 taxpayers with projected no-behavioral-response AGIs between $\$ 200,000$ and $\$ 220,000$. This average is $\$ 157,000$ per return or a total of $\$ 6.6$ billion. We add this to the $\$ 364$ billion of ATI among taxpayers with

\footnotetext{
${ }^{21}$ Recall that by looking at AGIs over $\$ 100,000$ they were able to write that the taxes paid by high income taxpayers rose $\$ 16$ billion while the taxable incomes of all others rose only $\$ 3$ billion. The $\$ 3$ billion increase refers to full taxable incomes not just the adjusted taxable income.
} 
observed AGIs over $\$ 200,000$ in 1993 to have a figure of $\$ 370$ billion of actual taxable income that can be compared to our no-behavioral-response estimate of $\$ 399$ billion.

\section{Taxpayer Responses and the Net Revenue Effects of the 1993 Tax Rate Increases.}

The analysis of section 2 provides the key estimates that we need to evaluate the effect of the taxpayers' behavior in response to the 1993 tax rate increases. Our analysis implies that if taxpayers had not changed their behavior in response to the higher marginal tax rates, those taxpayers with 1993 AGIs over $\$ 200,000$ would have reported total adjusted taxable income (excluding capital gains) of $\$ 399$ billion while the actual total adjusted taxable income was $\$ 370$ billion, a decline of $\$ 29$ billion or 7.3 percent.

Consider what this decline in adjusted taxable income did to tax revenue. Our TAXSIM analysis implies that raising tax rates from 31 percent to 36 percent and 39.6 percent would have increased the 1993 tax paid by high income taxpayers by $\$ 19.3$ billion if the no-behavioral-response level of adjusted taxable income ( $\$ 399$ billion) had occurred. ${ }^{22}$ In contrast, with the actual modified taxable income reduced to $\$ 370$ billion, the personal income tax revenue raised with the 1993 tax rates is only $\$ 8.8$ billion. This implies that taxpayer responses reduced the increase in personal income tax revenue by $\$ 10.7$ billion. This $\$ 10.7$ billion revenue leakage due to taxpayer responses was equal to 55 percent of the "static" (no behavioral response) projected revenue gain. In short, the observed experience in 1993 suggests that taxpayer responses reduced the increase in the personal

\footnotetext{
${ }^{22}$ This is quite consistent with the original Treasury estimates. Gerald Auten and Robert Carroll of the Treasury's Office of Tax Analysis published the Treasury's estimate of the increase in tax liabilities (Auten and Carroll, 1994). They report a static estimate of $\$ 19.5$ billion and an estimated net of the long-run behavioral response that is 7 percent less.
} 
income tax revenue caused by the 1993 tax rate changes to less than one-half of what it would have been with no behavioral response.

In addition to this loss of personal tax revenue because of the reduction in taxable incomes, there was also a reduction in $\mathrm{HI}$ and OASDI payroll tax revenues. ${ }^{23}$ The $\$ 29$ billion reduction in taxable income corresponds to a reduction of $\$ 1.5$ billion of income subject to the full 15.3 percent OASDHI rate and to $\$ 5.6$ billion of compensation subject to the 0.029 percent $\mathrm{HI}$ tax. The implied loss of tax payroll tax revenue is thus $\$ 0.38$ billion.

Combining the personal tax increases and the losses of OASDHI payroll tax revenue implies that the 1993 personal income tax rate changes raised revenue of only $\$ 8.4$ billion. In comparison to the "static" no behavioral response projection of $\$ 19.3$ billion of additional revenue, this implies a revenue leakage of 57 percent.

\section{Uncompensated and Compensated Elasticities Implied by the 1993 Experience}

To calculate the compensated elasticity of taxable income with respect to the net of tax rate we begin with the uncompensated elasticity implied by the evidence in section 3 . We derive this number as the ratio of the percentage change in taxable income to the weighted average percentage change in the marginal net of tax rates.

The $\$ 29$ billion reduction in taxable income represents a 7.3 percent decline in taxable

\footnotetext{
${ }^{23}$ Recall that the increase in the tax base for the HI payroll tax did not begin until 1994. The calculations reported at this point in the paper therefore refer to the loss of $\mathrm{HI}$ and OASDI revenue caused by the reductions in taxable compensation in response to the higher personal income tax rates. The specific effect of the 1994 rise in the $\mathrm{HI}$ tax base is discussed in section 6 below.
} 
income. The percentage change in the net of tax rate varies with the type of income and the individual's initial tax level. The lowest percentage decrease in the net of tax rate relates to taxpayers with taxable income between $\$ 140,000$ and $\$ 250,000$ whose compensation exceeded the 1993 threshold for the HI tax of $\$ 135,000$. For such taxpayers, the marginal tax rate was initially 31 percent, implving a marginal net of tax share of 0.69 . The rise in the tax rate to 36 percent implies a percentage decline in the net of tax share of $0.05 / 0.69=0.072$. The same percentage decline applies also to noncompensation income on tax returns with taxable income under $\$ 250,000$. The largest percentage decline in the net of tax share applies to the small amount of wage income that was below the $\$ 57,600$ ceiling of the OASDHI tax base but is on a tax return with total taxable income over $\$ 250,000$. For such income, the initial marginal tax rate is $(0.31+0.153) /(1.077)=0.43$ so that the initial net of tax share is 0.57 . The increase in the marginal income tax rate to 0.396 implies a decline in the net of tax share to $1-(0.396+0.153) / 1.077=0.49$, a decline of 14 percent. Making a similar calculation for each of the six possible income groups ${ }^{24}$ and taking the weighted average ( using the amount of income of that type as the weight) produces an average decline in the net of tax share of 11 percent. Thus the uncompensated elasticity of taxable income with respect to the net of tax share is $\eta=0.073 / 0.11=0.66$.

This calculation is effectively a difference-in-difference estimator, using the difference between the taxable income changes in 1993 and 1992 for the $\$ 50,000$ to $\$ 200,000$ AGI class and the $\$ 200,000$-plus AGI class.

${ }^{24}$ For each of the two possible increases in the marginal personal income tax rate $(0.05$ and 0.086$)$ there are three groups defined by the associated payroll tax rate: wages below $\$ 57,600$; wages between $\$ 57,600$ and $\$ 135,000$; all other wage and nonwage income. 


\subsection{The Compensated Elasticity}

The uncompensated elasticity is less than the compensated elasticity that is needed to calculate the deadweight loss of the increased tax rates. The loss of net income caused by the higher tax rates induces taxpayers to work more, to make fewer tax deductible expenditures (e.g., charitable contributions). 'nd to take more income in cash rather than untaxed fringe benefits (e.g., attractive offices). This income effect causes the observed uncompensated decline in taxable income to be less than the compensated effect that would occur if there were no loss of net income.

Because the notion of a compensated elasticity of taxable income with respect to the net of tax rate is not a traditional concept ${ }^{25}$, some discussion is warranted. It is useful to begin with the traditional deadweight loss analysis that assumes that taxes distort only the supply of labor. The change in labor supply induced by a change in the net wage can be decomposed into a substitution effect and an income effect:

$$
\mathrm{dL} / \mathrm{d}(1-\mathrm{t}) \mathrm{w}=\{\mathrm{dL} / \mathrm{d}(1-\mathrm{t}) \mathrm{w}\}_{\mathrm{COMP}}+(\mathrm{dL} / \mathrm{dy}) \mathrm{dy} / \mathrm{d}(1-\mathrm{t}) \mathrm{w}
$$

where $\mathrm{L}$ is leisure (and $1-\mathrm{L}$ is total hours worked), $\mathrm{t}$ is the proportional tax rate, and dy is the rise in income that results from the tax rate reduction with no behavioral response. To obtain the corresponding uncompensated and compensated elasticities of labor supply, substitute $1-\mathrm{L}$ for $\mathrm{L}$ in each of the three derivatives of equation 1 , multiply both sides by $(1-t) /(1-L)$, note that $d y / d(1-t)=-$ $\mathrm{dy} / \mathrm{dt}=w(1-\mathrm{L})$, and write $\eta_{\mathrm{L}}$ for the uncompensated elasticity on the left hand side and $\varepsilon_{\mathrm{L}}$ for the compensated elasticity (the first term on the right hand side):

$$
\eta_{L}=\varepsilon_{L}+(1-t) w d(1-L) / d y .
$$

${ }^{25}$ This elasticity is introduced and discussed at length in Feldstein (1995c) on which this portion of the paper draws. 
If tax induced changes in labor supply are the only source of deadweight loss, the increase in the deadweight loss caused by an increase in marginal tax rates is given by

$$
\Delta \mathrm{DWL}=0.5 \varepsilon_{\mathrm{L}}\left[\left(\mathrm{t}_{2}{ }^{2}-\mathrm{t}_{1}{ }^{2}\right) /\left(1-\mathrm{t}_{1}\right)\right] \mathrm{w}(1-\mathrm{L})
$$

This traditional deadweight loss analysis ignores the effect of changes in the tax rate on the taxpayers' use of deductions and on the shift of compensation to excludable forms (fringe benefits, work environment, etc.). As shown in Feldstein (1995c), the more comprehensive deadweight loss that takes into account deductions and exclusions as well as the labor-leisure substitution can be written in the same form as equation 3 but with the labor supply elasticity replaced by the compensated elasticity of taxable income with respect to the net of tax rate and with labor income $[\mathrm{w}(1-\mathrm{L})]$ replaced by taxable income:

$$
\Delta D W L=0.5 \varepsilon_{T 1}\left[\left(t_{2}^{2}-t_{1}^{2}\right) /\left(1-t_{1}\right)\right] T I
$$

The compensated elasticity of taxable income can be derived from the uncompensated elasticity that we have estimated here by a decomposition similar to equation 1:

$$
\mathrm{dTI} / \mathrm{d}(1-\mathrm{t})=\{\mathrm{dTI} / \mathrm{d}(1-\mathrm{t})\}_{\mathrm{COMP}}+(\mathrm{dTI} / \mathrm{dy})(\mathrm{dy} / \mathrm{d}(1-\mathrm{t})
$$

or, in elasticity form,

$$
\eta_{\mathrm{Tl}}=\varepsilon_{\mathrm{Tl}}+(1-\mathrm{t})\left(\mathrm{dt}_{\mathrm{a}} / \mathrm{d}(1-\mathrm{t})\right)(\mathrm{dTI} / \mathrm{dy})
$$

where data is the change in the average tax rate on taxable income.

Since we have an estimate of $\eta_{\mathrm{TI}}=0.66$, we can estimate $\varepsilon_{\mathrm{TI}}$ by calculating the value of $(1-t)\left(d_{a} / d(1-t)\right)(d T I / d y)$. Consider first the value of dTI/dy, the change in adjusted taxable income that would result from an incremental dollar of exogenous income. An increase in exogenous income induces individuals to increase their consumption of leisure (wL), to spend more on tax deductible items like charitable giving (D), and to take more of their potential compensation in the form of 
fringe benefits and favorable working conditions that are excluded in the definition of taxable income (E). Thus $d T I / d y=-d w L / d y-d D / d y-d E / d y$.

The first of these terms is the traditional income effect on the demand for leisure. The labor supply literature suggests that $\mathrm{d} w \mathrm{w} / \mathrm{dy}$ is approximately 0.10 to $0.15 .^{26}$

In an earlier paper, Feldstein (1995c) estimated the effect of an increase in exogenous income on deductible consumption ( $\mathrm{dD} / \mathrm{dy}$ ) by a regression of itemized deductions on AGI (using the TAXSIM model with individual tax return data for 1991) holding the marginal rate constant. ${ }^{27}$ To focus on those itemized deductions that represent deductible consumption ${ }^{28}$, the measure of deductions used in the regressions excludes income taxes paid to state and local governments and nonmortgage interest deductions. Among taxpayers in 1991 in the highest marginal tax bracket (with first dollar marginal tax rates before deductions of 31 percent), the change in deductibles per dollar of AGI was 7.1 cents.

We can think of no good way to estimate the effect of exogenous income on the amount of excluded compensation (dE/dy). A large part of excluded compensation is health benefits and these are relatively insensitive to income, especially among the very high income taxpayers. Pension funds vary with wages and salaries but are not likely to be affected by the receipt of an exogenous lump

\footnotetext{
${ }^{26}$ The estimated income effect in the labor supply literature is based on the response of participation rates and hours worked. This omits the long-run effect on such things as career choice and location. The restricted definition of labor supply causes the estimated compensated elasticity to be an underestimate of the true long-term response.

${ }^{27}$ This discussion of $\mathrm{dTI} / \mathrm{dy}$ draws heavily on that paper.

${ }^{28}$ Only those deductions that represent consumption are relevant for calculating the deadweight loss of the distorting effect of tax rates on taxable income; see Feldstein (1995c).
} 
sum income. Other forms of excludable income, including the quality of the work environment, are likely to be more sensitive. We follow Feldstein (1995c) and assign a value of 0.15 to dE/dy.

Combining the three components of $d T I=-d w L / d y-d D / d y-d E / d y$ implies that $d T I / d y=-$ 0.37. Our data do not allow us to assign different values of dTI/dy to different groups of taxpayers and any attempt to do so would suggest more information than we have. We therefore use dTI/dy $=-0.37$ for all taxpayers.

The other terms in equation $6\left[(1-t)\left(\mathrm{dt}_{\mathrm{a}} / \mathrm{d}(1-\mathrm{t})\right]\right.$ do differ among taxpayers according to the taxpayer's initial level of taxable income, i.e., the level of income with no behavioral response.. The net-of-tax rate (1-t) equals 0.69 except on income that is subject at the margin to the social security and HI payroll taxes. Thus noncompensation income and compensation income above $\$ 135,000$ have a net of tax rate of 0.69 . Compensation that is subject to the 2.9 percent employer employee rate but not to the social security (OASDI) tax, i.e., compensation between $\$ 57,600$ and $\$ 135,000$ have an initial marginal tax rate of $(.31+.029) /(1.0145)=0.334$ where the denominator of this fraction reflects the empivyers share of the pay w wl tax, implying a net of tax rate of 0.666 . Similarly, for those with incomes below $\$ 57,600$ who were - bject to the full 15.3 percent payroll tax, the initial marginal tax rate was $(0.31+0.153) /(1.077)=0.430$, implying a net of tax rate of 0.570 .

Consider next the value of $\left(\mathrm{dt}_{\mathrm{a}} / \mathrm{d}(1-\mathrm{t})\right)$, the ratio of the change in the average tax rate to the change in the marginal tax rate. For an individual with taxable income at exactly $\$ 140,000$, the 1993 tax rates increased the marginal tax rate from 0.31 to 0.36 but left the tax liability and therefore the average tax rate unchanged. For such an individual, $\mathrm{dt}_{\mathrm{a}} / \mathrm{d}(1-\mathrm{t})=0$ and there is no income effect. At incomes between $\$ 140,000$ and $\$ 250,000$, the average tax rate increases by 0.05 times the ratio of the taxable income above $\$ 140,000$ to total taxable income. In this range, therefore, $\mathrm{dt}_{\mathrm{a}} / \mathrm{d}(1-\mathrm{t})$ is 
equal to the ratio of taxable income above $\$ 140,00$ to total taxable income. At a taxable income of $\$ 250,000$ the marginal tax rate jumps from 36 percent to 39.6 percent, temporarily reducing $\mathrm{dt}_{\mathrm{a}} / \mathrm{d}(1-\mathrm{t})$. After that, the ratio rises again toward a limiting value of 1.0 .

We have calculated the value of $(1-t)\left(\mathrm{dt}_{\mathrm{a}} / \mathrm{d}(1-\mathrm{t})\right)$ for each taxpayer, multiplied that amount by $-\mathrm{dTI} / \mathrm{dy}=0.37$ and added the estimate of the uncompensated elasticity $\eta=0.66$ to obtain an estimate of the compensated elasticity for that taxpayer. The weighted average of these compensated elasticities, weighting by the projected 1993 adjusted taxable income for that individual, is $\varepsilon=0.74$.

This weighted average compensated elasticity for high income taxpayers implied by the 1993 experience seems quite consistent with the compensated elasticity found by Feldstein (1995a) and by Auten and Carrol (1994) on the basis of the experience of a large panel of taxpayers before and after the 1986 tax cuts. The estimate preferred by Feldstein was 1.04 while the Auten-Carrol estimate was 1.33 . The lower value of the current estimate of 0.74 may reflect the short-run nature of the observation for 1993 since the observed behavior refers to the same year in which the tax rate was chang d. We return to that issue in section 7.

\section{The Deadweight Loss of the 1993 Increase in Personal Tax Rates}

The compensated elasticities $\varepsilon_{\mathrm{TI}}$ calculated for each type of income of each taxpayer according to equation 6 can be used to estimate the deadweight loss for that taxpayer of increasing the marginal personal income tax rates from 31 percent to 36 percent and 39.6 percent. In this calculation, the marginal tax rate also includes the marginal payroll tax rate (if any). ${ }^{29}$ For example,

\footnotetext{
${ }^{29} \mathrm{We}$ use the expression in equation 4 to calculate the increased deadweight loss due to the change in the tax on each particular type of income. As noted earlier, we make no allowance 
an individual with taxable compensation between $\$ 57,600$ and $\$ 135,000$ who is part of a taxpaying unit with total taxable income between $\$ 140,000$ and $\$ 250,000$ experiences a marginal tax rate increase on that income from $(0.31+0.029) /(1.0145)=0.334$ to $(0.36+0.029) /(1.0145)=0.383$.

When the increased deadweight losses are aggregated over all the individuals we obtain a total increase in the deadweight loss due to the 1993 increase in personal income tax rates of $\$ 15.9$ billion. ${ }^{30}$

This estimated increase in deadweight loss is thus nearly twice the estimated increase in tax revenue. Stated differently, for every dollar that the government collects as a result of the increase in the top personal income tax rates, the taxpayers incur a total cost of nearly three dollars -- the dollar transferred to the government plus the deadweight loss of nearly two dollars.

The structure of the 1993 tax increase thus made it a very inefficient way of increasing revenue.

\section{The Effects of the Increase in the HI Tax Base}

Although elimination of the $\$ 135,000$ ceiling on the HI tax base was enacted at the same time as the increase in personal income tax rates, it only took effect in January 1994. Our evidence

for cross-price effects. We calculate each deadweight loss separately and then add them.

${ }^{30}$ Of this $\$ 16.6$ billion, more than 70 percent ( $\$ 11.8$ billion) is associated with the increase from 31 percent to 39.6 percent. Of this $\$ 11.8$ billion, very little involves marginal payroll tax rates; $\$ 6.4$ billion is associated with compensation over $\$ 135,000$ and $\$ 4.0$ billion is associated with noncompensation income. In contrast, of the $\$ 4.8$ billion increase in the deadweight loss associated with the rise in the marginal tax rate from 31 percent to 36 percent, $\$ 3.4$ billion is associated with income that is subject to a marginal payroll tax rate at 2.9 percent ( $\$ 2.0$ billion) or 15.3 percent ( $\$ 1.4$ billion). 
therefore does not relate to the effect of that part of the tax increase. ${ }^{31}$ We can however use our estimated elasticities to calculate the likely effect of the increased $\mathrm{HI}$ tax on tax revenue and on the deadweight loss.

Consider first the ways in which eliminating the ceiling on the HI tax base changes total tax revenue. Because the higher marginal tax rate causes a decline in taxable income, the additional $\mathrm{HI}$ tax is less than the amount that would have been collected if there were no behavioral response. More important, however, the decline in taxable income also reduces the income subject to the personal income tax and therefore reduces the personal income tax revenue.

These effects can be illustrated with the example of an individual who, with the behavior induced by the 1993 marginal tax rates, would have taxable income of $\$ 220,000$ in 1993 and taxable compensation of $\$ 200,000,{ }^{32}$ Under the 1993 tax rules, that individual faced a marginal personal income tax rate of 36 percent and no marginal payroll tax. Under the 1994 tax rules, the individual would also face a combined employer-employee payroll tax of 2.9 percent, implying that the tax as a percentage of the individual's marginal product rises from 0.36 to $0.389 /(1.0145)=0.383$. The net of tax rate thus falls from 0.64 to 0.617 , a decline of 3.6 percent. The estimated uncompensated elasticity of $\eta=0.66$ implies that the individual's taxable income declines by 2.4 percent, from $\$ 220,000$ to $\$ 214,720$. If the compensation portion declines in the same proportion, taxable compensation falls from $\$ 200,000$ to $\$ 195,200$. The additional HI tax is 2.9 percent of the difference

31 As noted above, our analysis ignored the fact that taxpayers who were aware that the HI tax would increase in 1994 had an incentive to advance income into 1993. This causes us to underestimate the uncompensated and compensated elasticities.

32 The difference between taxable income and taxable compensation is the difference between nonlabor income and itemized deductions. 
between $\$ 195,200$ and $\$ 135,000$ or $\$ 1745$. But the induced decline in taxable income of $\$ 5,280$ (from $\$ 220,000$ to $\$ 214,720$ ) reduces personal tax collections at a 36 percent rate, i.e., by $\$ 1901$. For this taxpayer, the increase in the HI tax base actually reduces total tax payments by $\$ 156$.

At higher incomes, the extra payroll tax can outweigh the loss of personal tax revenue. Consider, for esample, a taxpayer with a taxable inc $>$ me of $\$ 330,000$ and taxable compensation of $\$ 300,000$. Under the 1993 tax rules, that individual faced a marginal personal income tax rate of 39.6 percent and no marginal payroll tax rate. Under the 1994 tax rules, the individual would also face a combined employer-employee payroll tax of 2.9 percent, implying that the tax as a percentage of the individual's marginal product rises from 0.396 to $0.425 /(1.0145)=0.419$. The net of tax rate thus falls from 0.604 to 0.581 , a decline of 3.8 percent. The estimated uncompensated elasticity of $\eta=0.66$ implies that the individual's taxable income declines by 2.51 percent, from $\$ 330,000$ to $\$ 324,720$. If the compensation portion declines in the same proportion, taxable compensation falls from $\$ 300,000$ to $\$ 292,470$. The additional $\mathrm{HI}$ tax is 2.9 percent of the difference between $\$ 292,470$ and $\$ 135,000$ or $\$ 4,566$. But the induced decline in taxable income of $\$ 8280$ (from $\$ 330,000$ to $\$ 321,720$ ) reduces personal tax collections at a 39.6 percent rate, i.e., by $\$ 3278$. For this taxpayer, the increase in the HI tax increases total tax collection by only $\$ 1,288$ or only 27 percent of the static revenue estimate of 2.9 percent of the $\$ 165,000$ increased tax base at the initial level of compensation.

In the aggregate, we estimate that eliminating the $\$ 135,000$ ceiling on the $\mathrm{HI}$ tax base reduced the predicted revenue (at 1993 income levels) from $\$ 2.1$ billion with no behavioral response to only $\$ 600$ million if taxpayers reduced their compensation (i.e., total wage and salary income plus schedule $\mathrm{C}$ income) in the same proportion that the 1993 experience implied for total taxable 
income. Only when the data for 1994 become available will it be possible to calculate the actual 1994 revenue response.

\subsection{The Deadweight Loss of the Increased HI Tax base}

Consider next the deadweight loss caused by raising the level of income subject to the HI tax. There is of course no change in the deadweight loss for those categories of income that experience no change in the HI tax. This includes the compensation earned by individuals with compensation under $\$ 135,000$ as well as all nonlabor income. ${ }^{33}$ The deadweight loss needs to be evaluated only for individuals with taxable compensation over $\$ 135,000$. There are two cases within this group: those with 1993 marginal tax rates of 36 percent and those with 1993 marginal tax rates of 39.6 percent. For each taxpayer we evaluate the change in deadweight loss if the tax rate on compensation increases from .36 to $.389 / 1.0145=0.383$ or, for higher income taxpayers, from .396 to $.425 / 1.0145=0.419$.

The two cases discussed earlier in this section illustrate the nature of the calculation. For the taxpayer with $\$ 220,000$ of taxable income and $\$ 200,000$ of taxable compensation at 1993 rates, only the $\$ 200,000$ is relevant for evaluating the deadweight loss of the increase in the HI ceiling. Equation 4 implies that the increased deadweight loss for this individual is:

$$
\begin{aligned}
\Delta \mathrm{DWL} & =0.5 \varepsilon_{\mathrm{TLI}}\left\{\left[(0.383)^{2}-(0.360)^{2}\right] /[1-0.360]\right\} 200,000 \\
& =2680 \varepsilon_{\mathrm{TLI}}
\end{aligned}
$$

where $\varepsilon_{\mathrm{TLI}}$ is the elasticity of taxable labor income to the net of tax rate for such compensation.

${ }^{33}$ In calculating the deadweight loss of the increased tax on compensation, we ignore any possible compensated cross-price effects and therefore look only at the effect of the increased marginal tax rate on the behavior of that type of income. 
The value of $\varepsilon_{\mathrm{TLI}}$ is not likely to be the same as the taxable income elasticity $\varepsilon_{\mathrm{TI}}$ because changes in the payroll tax rate do not provide any incentive to change deductions. To evaluate $\varepsilon_{\mathrm{TL}}$ it is useful to consider first the corresponding uncompensated elasticity of taxable labor income with respect to the corresponding net of tax rate. The elasticity of overall taxable income with respect to the net of tax rate $(\eta=0.66)$ reflects the effect of the tax on labor supply, on the form of labor compensation (fringe benefits and working conditions versus cash) and on the use of deductibles. The elasticity of taxable compensation, which we label $\eta_{\mathrm{TLI}}$, includes the first two of these but does not include the use of deductibles. It also includes an additional component: the substitution between taxable labor income and other forms of income. The 2.9 percent payroll tax gives individuals an incentive to shift income from taxable compensation to investment income. Although such a substitution may not be possible for most taxpayers, high income individuals that are our focus here may be able to shift the form of compensation from labor income to rent, royalties, stock options, capital gains, etc. It is difficuit to know the magnitude of this compensationnoncompensation substitution relative to the effect of the income tax on the use of itemized deductions. The difference may cause either a rise or a fall in going from the elasticity of taxable income to the elasticity of taxable labor income. To be very conservative, we shall set $\eta_{\mathrm{TL}}=0.50$, approximately two-thirds of the estimated elasticity of taxable income. We recognize that this is only an educated guess but we think it is likely to be a conservative one.

The same analysis of income and substitution effects that lead to equation 6 implies that

$$
\eta_{\mathrm{TL}, 1}=\varepsilon_{\mathrm{TLI}}+(1-\mathrm{t})\left(\mathrm{dt}_{\mathrm{a}} / \mathrm{d}(1-\mathrm{t})\right)(\mathrm{dTLI} / \mathrm{dy}) .
$$

For the individual with taxable compensation of $\$ 220,000$ and taxable labor income of $\$ 200,000$, the initial marginal tax rate is 36 percent, implying that $(1-t)=0.64$. Since the payroll tax increase 
is at a constant rate above the $\$ 135,000$ threshold, the ratio $\mathrm{dt}_{\mathrm{a}} / \mathrm{d}(1-\mathrm{t})$ is the ratio of the newly taxable compensation (in this case $\$ 200,000-\$ 135,000=\$ 65,000)$ to total compensation: $\left(\mathrm{dt}_{\mathrm{a}} / \mathrm{d}(1-\mathrm{t})=\right.$ 0.325. The value of $\mathrm{dTLI} / \mathrm{dy}$ is the effect on taxable labor income of an increase in exogenous income. Omitting the decline in deductible expenditures $(\mathrm{dD} / \mathrm{dy}$ that represented 0.071 of the estimated value of $d T I / d y=-0.37$ ) leaves the effect of exogenous income on the consumption of leisure and on the use of excludable income like fringe benefits. Unlike the substitution effect, there is no reason why an exogenous income increase should induce a change from taxable labor income to nonlabor income. We therefore take $\mathrm{dTLI} / \mathrm{dy}=-0.30$.

Substituting these estimates into equation 8 implies $\varepsilon_{\mathrm{TLI}}=\eta_{\mathrm{TL}}+0.66(0.325)(0.30)=\eta_{\mathrm{TL}}$ $+0.06=0.56$. Equation 7 implies that the deadweight loss of the $\mathrm{HI}$ increase for this taxpayer is $\$ 1501$. Thus the government collects $\$ 316$ less in revenue than without the higher HI tax but imposes a deadweight loss of $\$ 1501$.

Consider next the example of the higher compensation taxpayer with $\$ 300,000$ The deadweight loss is based on increasing the marginal tax rate from 0.396 to 0.419 :

$$
\begin{aligned}
\Delta \mathrm{DWL} & =0.5 \varepsilon_{\mathrm{TLI}}\left\{\left[(0.419)^{2}-(0.396)^{2}\right] /[1-0.390 ́]\right\} 300,000 \\
& =4665 \varepsilon_{\mathrm{TLI}}
\end{aligned}
$$

In this case, equation 8 implies that $\varepsilon_{\mathrm{TLI}}=0.60$. The deadweight loss is therefore $\$ 2799$ while the increase in revenue is only $\$ 966$. The total burden is thus nearly four times as much as the revenue raised.

We have calculated the increased deadweight loss for each of the affected taxpayers. The aggregate amount of the deadweight loss is $\$ 2.1$ billion or more than three times the $\$ 600$ million net revenue gain from eliminating the ceiling on the HI taxbase. 


\section{Potential Biases in the Estimated Taxpayer Response}

In interpreting these results and comparing them to the earlier studies of the effects of the tax rate reductions in the 1980 s, several potential sources of statistical bias should be borne in mind. Some of these cause our estimates to overstate the true long-term effect of the change in tax rates while others cause our estimates to understate that true effect. This section discusses those biases and the future research that may help to resolve the resulting uncertainty as better data become available.

\subsection{Short run response}

First, the current analysis refers to the changes in taxpayer behavior during the same year that Congress enacted the change in tax rates. Because it takes time for taxpayers to alter their behavior in response to the higher tax rates, our estimated first year response may understate the longer term effect of the tax rate increases. ${ }^{34}$ This longer term effect might, for example, involve changing jobs or employers to one with a more pleasant life style but lower cash income. If this type of change is more pronounced among younger individuals who are still making career choices, it will affect the population as a whole culy gradually. Simila.iy, older individuals may respond to the higher tax rates by advancing the date of their retirement or $\because$ choosing a mix of more retirement and less work. Again it takes time before such decisions, made in a relatively narrow range of years, come to have a significant effect on the activity of a large segment of the labor force. All of these considerations suggest that the long-run effect will be greater than the short-run effect that has been observed in the present study. A similar difference may also apply to changes in deductions (e.g.,

${ }^{34}$ The Treasury Department's estimates assume that the behavioral responses in the narrow range of changes that they consider do increase from a 7 percent revenue loss in the first year to a long run behavioral response that reduces revenue by 16 percent in year 5 and beyond. See Auten and Carroll (1994b). 
the size of a mortgage or the purchase of a second home) and in exclusions (the employer's provision of more fringe benefits instead of larger increases in cash salaries.)

The observed same-year effect for 1993 may have been depressed further relative to the potential long term effect by the fact that the legislation wasn't enacted until August of that year. Although the tax rate increases for high income individuals were enacted as proposed in February 1993, other aspects of the President's tax plan were radically changed. Many taxpayers may therefore have waited until after August to begin changing their behavior.

In contrast to the current paper, the earlier studies of the effects of lower tax rates generally were based on taxpayer behavior two years or more after the tax cut. It is not surprising therefore that the estimated elasticities in the current study are substantially less than the elasticities estimated for the 1981 and 1986 tax rate reductions.

We will be able to remedy this problem when we have data for a longer period of time after 1993. For the reasons discussed later in this section, panel data through 1995 will be particularly valuable in estimating the longer-term response.

\subsection{Shifting of Income from 1993 to 1992}

A second potential source of statistical bias could result from shifts of bonuses and other income from 1993 to 1992 . Taxpayers who anticipated the 1993 tax increase may have taken steps to shift income from 1993 to 1992 . The Treasury Department, in commenting on an earlier draft of our study, pointed to a Department of Commerce estimate that $\$ 20$ billion of wage and salary income (including bonuses) was shifted from the first quarter of 1993 to the final quarter of 1992 and argued that our statistical estimate of a $\$ 29$ billion loss of taxable income could be explained by such a one-time shift on the assumption that virtually all of the income shifting was among 
taxpayers with AGI greater than $\$ 200,000$.

It is important to recognize, however, that because of our difference-in-difference method of estimation, a shift of income from 1993 to 1992 only biases our estimate of the tax-induced change in taxable income in this way if the intertemporal shift of income is a larger share of taxable income amnng the taxpayers in the $\$ 200,000$-plus AGI group than among taxpayers in the $\$ 50,000$ to $\$ 200,000$ reference group. There is unfortunately no evidence on the distribution of income shifting. Moreover, wage and salary income constitutes only about two thirds of total taxable income among the top group but is actually equal to about $i 20$ percent of taxable income among those in the reference group (because their adjustments and deductions exceed their non-wage incomes.) This implies that an intertemporal shift of income that was the same fraction of wages in the two groups would cause the rise in taxable income among the high income group to be substantially greater than among the reference group. In that case, the income shifting would cause our difference-in-difference procedure to underestimate the true effect of the higher tax rates. Indeed, unless the relative wage shift was at least 80 percent higher among the top AGI group than among the reference group, the shifting would cause our estimate to understate the true effect of higher tax rates.

While the top income group had a greater incentive to shift incomes, many in the reference group believed that they also had reason to shift income. As the 1994 Economic Report of the President notes, as late as July 1993 over 70 percent of respondents to a Wall Street Journal/NBC poll thought that middle class taxpayers would bear most of the tax increases (page 74).

There is of course some doubt about the accuracy of the estimated $\$ 20$ billion of aggregate shifting. The $\$ 20$ billion shift of wage and salary income from the first quarter of 1993 to the final 
quarter of 1992 is reported in the national income accounts as $\$ 20$ billion of "wage accruals less disbursements". This is the only time (at least in the past 25 years for which we have data) in which the Commerce Department estimates a wage accruals less disbursements in excess of $\$ 1$ billion. The staff of the Bureau of Economic Analysis explain in the August 1993 Survey of Current Business (page 28) that the method of estimating annual wage and salary accruals was changed for 1992 to reflect the possibility of a large amount of bonuses paid in 1992. This change was made because in early 1993 "reports indicated that bonus payments earned by many employees in the securities industry in 1992 that typically would have been paid in early 1993 had instead been paid in late 1992." The BEA initially estimated that $\$ 1.5$ billion in bonus payments had been accelerated from 1993 to 1992 . Later, on the basis of a comparison of the quarterly unemployment insurance reports of covered wages for the fourth quarter of 1992 with the corresponding fourth quarter reports for the prior years back to 1982 , the BEA revised its estimate and "concluded that about $\$ 20$ billion" of fourth quarter 1992 wage and salary income represented an acceleration of bonus payments from early 1993. This assumption was used by the BEA to estimate that the "wage accruals less disbursements" figure for the first quarter of 1993 was a negative $\$ 20$ billion.

Estimating the extent of wage and salary shifting in the fourth quarter of 1992 is difficult because that quarter saw a quite dramatic surge of GDP. The rise in nominal GDP jumped from an annual rate of 4.9 percent in the third quarter of 1992 to 8.6 percent in the fourth quarter and then fell back again to 4.4 percent in the first quarter of 1993 . Shifts in the timing of compensation would not affect these GDP estimates since any shift in wage payments would cause a corresponding shift in profits. Since wage and salary payments are about half of GDP, a 4.9 percent increase would correspond to about $\$ 150$ billion while an 8.6 percent increase would correspond to about $\$ 260$ 
billion. Deciding how much of the observed $\$ 125$ billion increase in wage disbursements (seasonally adjusted) between the third and fourth quarters of 1992 was a "shift in timing " and how much was a result of the economic surge is a very difficult judgement to make.

We have however followed the procedure described by the BEA and examined the fourth quarter through insurance reports on covered wage and salary payments from 1982 to 1992 . The fourth quarter of 1992 shows a substantial jump in reported wage and salary income, from the roughly $\$ 65$ billion increase in the previous two years to a $\$ 106$ billion increase in 1992 . Again, it is difficult to know how much of this is due to the fact that nominal GDP rose at 8.6 percent in the fourth quarter of 1992 but at only 2.6 percent in the fourth quarter of 1991 and 0.5 percent in the fourth quarter of 1990.

We were also encouraged by the Treasury Department to examine the evidence on the change in income tax withholding between the end of 1992 and the beginning of 1993 that is published in the monthly Treasury Bulletins. Although the data are available monthly, the number of working days and the number of pay periods varies from month to month and year to year. We have therefore examined quarterly data on tax withholding. Between the fourth quarter of 1992 and the first quarter of 1993 , tax withholding fell by $\$ 6.2$ billion. However, there was an equally large drop a year later (a $\$ 6.2$ billion decline in tax withholding between the final quarter of 1993 and the first quarter of 1994 ) and a decline that was almost as large in the previous year (a decline on $\$ 4.0$ billion from the first quarter of 1991 to the first quarter of 1992). It is hard to conclude from the Treasury data that anything unusual occurred at the end of 1992.

\subsection{Shifting of Income from 1994 to 1993}

High income taxpayers also had an incentive to shift income from 1994 to 1993 . To the 
extent that such shifting occurred and that it was relatively greater than the shifting among those in the $\$ 50,000$ to $\$ 200,000$ AGI class, our estimates would understate the effect of the 1993 tax rate increases.

One reason for the high income taxpayers to shift income from 1994 to 1993 was to avoid the 2.9 percent payroll tax scheduled to begin in January 1994. For a taxpayer with a 39.6 percent marginal rate of personal income tax, eliminating the ceiling on income subject to the $\mathrm{HI}$ tax raised the marginal tax rate to 41.9 percent. The next of tax share thus decreased by 3.8 percent.

There was moreover substantial uncertainty even in 1993 about whether the Administration's proposal would be enacted and, if enacted, whether it would be "retroactive" to January 1993. Many high income taxpayers hoped that tax rates for 1993 would be increased only part of the way to the full higher rates that would begin in 1994. Those who thought that there was some possibility that the rates would be lower in 1993 than in 1994 had an incentive to advance income from future years to 1993 , e.g., by shifting a bonus from 1994 to 1993 or by ending a deferred compensation arrangement.

The change in the alternative minimum tax provided another reason why some taxpayers might have shifted some income from 1994 to 1993 . The AMT raises an individual's overall tax liability by eliminating deductions and adjustments to income that would be allowed under the ordinary income tax but taxes that greater taxable income at a lower marginal rate than the ordinary income tax. The current AMT rate is 26 percent. An individual who faced the AMT in 1993 but expected to avoid the AMT in 1994 would have an incentive to shift compensation from 1994 to 1993 to take advantage of the lower overall tax rate.

Although the official estimates of "wage accruals less disbursements" show no unusual 
activity at the end of 1993 , the underlying evidence used by the BEA to impute $\$ 20$ billion value of "wage accruals less disbursements" to the final quarter of 1992 suggests an approximately equally large adjustment for the final quarter of 1993 . We have already noted that the Treasury withholding receipts fell by exactly the same amount from the end of 1993 to start of 1994 as it did between the end of 1992 and the first quarter of 1993. In addition, the wages covered by unemployment insurance reported for the fourth quarter of 1993 also jumped by a large $\$ 97$ billion (similar to the $\$ 106$ billion in the final quarter of 19932) before reverting to $\$ 64$ billion in the final quarter of 1994 , the same level that had prevailed in the final quarters of 1990 and 1991.

It is impossible to use the currently available tax data itself to sort out the role of shifting versus sustained taxable changes in taxable income. Only when panel data through 1995 become available will it be possible to address this issue in a fully satisfactory way.

\subsection{Assuming No Tax Increases in the $\$ 50,000$ to $\$ 200,000$ AGI Reference Group}

The difference-in-difference method assumes that the tax rates increased among those with AGI's greater than $\$ 200,000$ but that there were no tax rate increases in the "reference" group with AGI's between $\$ 50,000$ and $\$ 200,000$. In fact, some taxpayers in this reference group (about 3 percent overall and 10 percent among those with AGIs between $\$ 100,000$ and $\$ 200,000$ ) did have incomes high enough to make them subject to the 1993 rise in tax rates. This "contamination" of the reference group means that the assumed change in tax rates between the two groups is larger than the actual one. This in turn causes an underestimate of the sensitivity of taxable income to the rise in tax rates and a corresponding underestimate of the implied elasticity.

\subsection{Lack of Panel Data}

The current study is not based on actual panel data that would allow following the same 
individuals through time as tax rates change. Although the earlier studies of the 1986 tax reductions using panel data were consistent with previous studies using the current type of "synthetic" panel data, the lack of actual panel data does introduce additional uncertainty in the estimates. The individuals in the highest income group are not the same in 1993 and 1992, a problem that is compounded hv the fact that AGI includes capital gains while our focus is on the taxable income excluding capital gains. Moreover, the reference group is necessarily defined in terms of nominal income levels rather than real income levels or equal numbers of taxpayers. We do not see any reason why this should bias the results but recognize that it does introduce additional uncertainty that would not be present with panel data.

The problem of comparing groups in different years becomes greater as the time between the years increases. For that reason, we were reluctant to extend our analysis from the comparison of 1993 and 1992 to earlier years. We did however repeat our analysis using 1991 as a reference year. More specifically, we used the change in taxable incomes between 1991 and 1993 of the group with nominal AG!s of $\$ 50,000$ to $\$ 200,000$ as the standard for predicting the rise in taxable incomes among those with AGIs over $\$ 200,000$. Unlike the 1992 based comparison, the 1991 based comparison showed no tendency to overestimate the taxable income of the high income group. There is no way to know whether this reflects the statistical biases associated with income shifting, the reduced comparability of taxpayers in the same AGI groups when we go from one year to two based on nominal income classification, or the very strong business cycle recovery that occurred in 1991. Only good panel data from 1991 through 1995 will be able to provide a fully reliable answer to this question. 


\subsection{Assuming a Stable Income Distribution}

The difference in difference approach implicitly assumes that the relative rates of increase of taxable incomes would have been the same in the high income group and in the reference group if there had been no change in tax rates. A substantial amount of evidence suggest that higher incomes are in fact rising more rapidly. Although some of this may itself be tax induced, there is substantial evidence that higher incomes are rising more rapidly than lower incomes for non-tax reasons as well.

To the extent that the high income taxpayers would have had greater income increases than taxpayers in the reference group in the absence of a tax change, our difference in difference method causes us to underestimate the true effect of the rise in tax rates. It would be desirable to try to estimate the extent of the likely change in income distribution due to nontax factors. This too will be helped when we have data that extends to at least 1995 since that eliminates any possible distortions due to temporary income shifting between 1993 and 1994. It would be desirable also to analyze this in a way thi..t separates cyclical ir..7uence on the income distribution.

\section{Conclusions and Caveats}

Several tentative conclusions emerge from this study. First, the basic estimates suggest that taxpayers reduced their taxable incomes in response to the higher 1993 marginal tax rates. Although the reductions were not absolutely large, they were large enough to imply a loss of about half of the additional revenue that would have been raised by the 1993 tax rate increases if there had been no behavioral response.

Second, the implied elasticities are somewhat lower than the sensitivity reported in previous studies of the response to the tax rates decreases of the 1980s. This may reflect the fact that the 
current estimates relate to the taxpayer responses within the same year that the tax rate was enacted and that the legislation was enacted only in August of the year.

Third, the estimates imply that the structure of the 1993 tax rate increase resulted in very little net revenue despite the sharp increase in marginal tax rates. The estimated taxpayer response implies a loss of more than half of the additional personal income tax revenue that would have occurred with no behavioral response. The reduction in payroll tax revenue that resulted from reduced incomes increased the overall leakage of tax revenue to 5.7 percent of the static estimate. Instead of raising $\$ 19.3$ billion of additional personal income tax revenue, the higher marginal tax rates led to an estimated revenue increase of only $\$ 8.4$ billion. These estimates differ very much from the traditional and virtually "static" revenue estimates used by the Treasury Department and the Congressional Joint Tax Committee. ${ }^{35}$

Fourth, the behavioral response implies a compensated elasticity is about 0.74 . This in turn implies that increasing marginal tax rates from 31 percent to 36 percent and 39.6 percent raised the deadwight loss of the personal income tax by $\$ 15.9$ billion. Thus the 1993 personal tax rate increases raised the deadweight loss by approximately two dollars for every additional dollar of tax revenue.

Finally, we use the estimated response to the higher personal income tax rates in 1993 to evaluate the effect of the increase in the HI tax base that took effect in January 1994. The combined employer-employee tax of 2.9 percent raised payroll tax revenue of about $\$ 2.0$ billion. But the higher

\footnotetext{
${ }^{35}$ Recall that the Treasury department assumed that the revenue loss due to taxpayer responses would be only 7 percent of the static no-behavioral-response revenue (Auten and Caroll, 1994).
} 
marginal tax rates that resulted is likely to have caused a decline in personal income tax revenue of $\$ 1.4$ billion. The net effect of eliminating the $\$ 135.000$ ceiling on the HI tax base was therefore to raise total federal tax revenue by only $\$ 600$ million.

Several possible statistical biases could cause the estimated effect of the tax changes to either underestimate or overestimate the true long run effects. These are discussed in section 7. Only further research, preferably with panel data for a longer period of time, can resolve some of these uncertainties. But until these additional studies are done, it seems reasonable to conclude that the higher marginal tax rates in 1993 raised substantially less revenue than a static estimate would imply and imposed relatively large deadweight losses.

Cambridge, MA

November 1995 


\section{$\underline{\text { References }}$}

Auerbach, Alan. "The U.S. Fiscal Problem: Where We Are, How We Got Here, and Where We're Going,"NBER Macroeconomics Annual 1994, Stanley Fischer and Julio Rotemberg (eds.), Cambridge, MA: The MIT Press, 1994, pp 141-175.

Auerbach. Alan. "Tax Projections and the Budget: Lessons from the 1980s," American Economic Review, Vol. 85, No. 2, May 1995, pp 165-169.

Auten, Gerald and R. Carroll. "Taxpayer Behavior and the 1986 Tax Reform Act," Treasury Department Office of Tax Analysis, July 1994a.

Auten, Gerald and R. Carroll. Tax Rates, Taxpayer Behavior and the 1993 Act," Proceedings of the National Tax Association, 1994b.

Cruciano, Teresa. "Individual Income Tax Returns, Preliminary Data, 1993, Statistics of Income Bulletin, U.S. Department of Treasury, Internal Revenue Service, Summer 1995.

Eissa, Nada. "Taxation and Labor Supply of Married Women: The Tax Reform Act of 1986 as a Natural Experiment," NBER Working Paper No. 5023, February 1995.

Eissa, Nada. "Labor Supply and the Economic Recovery Act of 1981," forthcoming in M. Feldstein and J. Poterba, Empirical Foundations of Household Taxation, 1996.

Feenberg, Daniel and James Poterba. "Income Inequality and the Incomes of Very High Income Taxpayers," Tax Policy and the Economy, Vol. 7, James Poterba (ed.), Cambridge, MA: The MIT Press, 1993.

Feldstein, Martin. “The Case for Dynamic Analysis,” Wall Street Journal, December 14, 1994.

Feldstein, Martin. "The Effect of Marginal Tax Rates on Taxable Income: A Panel Study of the 1986 Tax Reform Act," Journal of Political Economy, June 1995a.

Feldstein, Martin. "Behavioral Responses to Tax Rates: Evidence from TRA86," American Economic Review, AEA Papers and Proceedings, Vol. 85, No. 2, May 1995b.

Feldstein, Martin. "Tax Avoidance and the Deadweight Loss of the Income Tax," NBER Working Paper No. 5055, $1995 \mathrm{c}$.

Feldstein, Martin and Daniel Feenberg. "Higher Tax Rates with Little Revenue Gain: An Empirical Analysis of the Clinton Tax Plan," Tax Notes, March 22, 1993. 
Feldstein, Martin and Daniel Feenberg. "The Taxation of Two Earner Families," NBER Working Paper No. 5155, June 1995, forthcoming in Martin Feldstein and James Poterba, (eds.,). Empirical Foundations of Household Taxation, 1996.

Lindsey, Lawrence. "Individual Taxpayer Response To Tax Cuts: 1982-1984, with Implications for the Revenue Maximizing Tax Rate," Journal of Public Economics, Vol. 33. 1987, pp 173-206.

Navratil, John. "Essay on the Impact of Marginal Tax Rate Reductions on the Reporting of Taxable Income on Individual Income Tax Returns," Doctoral Dissertation, Harvard University, 1995.

White House. A Vision of Change for America, Washington: Government Printing Office, 1993. 